DOI: $10.24014 /$ Jush.v29i2.13808

p-ISSN: 1412-0909

e-ISSN: $2407-8247$

\title{
Structural Analysis and Stilistic Meaning of Khabariyah Verses in The Qur'an
}

\author{
Agustiar and Khairunas Jamal
}

Universitas Islam Negeri Sultan Syarif Kasim Riau, Indonesia agustiarabbas354@gmail.com

\section{Article Information}

Submitted: Augustus, 4, 2021

Revised I: September,23,2021

Revised II: November, 25, 2021

Accepted: December, 27, 2021

\section{Keywords}

Structural analysis, stylistic meaning, verses of khabariyyah

\section{Abstract}

Al-Qur'an always displays the style of language in various forms. The diversity of the structure and language style of the Qur'an shows that there is a certain meaning that is displayed behind the text of the verse. This article aims to reveal the forms of linguistic structures and meanings contained in the khabariyyah verses in the Qur'an so that they can provide an alternative understanding of the Qur'an that does not favor one group. And can provide a clear understanding of meaning, open as it is in accordance with the form of a typical sentence structure in the form of speech and the meaning contained in it. The method used is Linguistic Theory by collecting the configuration of kalam khabariyyah then analyzing its structure and meaning through the Syntact and semantic analysisapproach in the Qur'an interpretation. This article concludes that the configuration of the stylistic structure of the verses with khabariyyah style in the Qur'an is expressed in two constructions, namely in the construction of the jumlah ismiyyah and jumlah fi'liyyah with various kind of its language style (uslub) there are : in the style of uslub al-Qashru, al-Taqdim wa al-Takhir, and al-Qasam. In terms of meaning, it shows that the Jumlah ismiyyah provides the permanent (Itsbat), eternal (Dawam) and continuous meaning (istimrar), while the jumlah fi'liyyah provides the occurrencemeaning (huduts) that means the occurrence of an event at a certain time as well as the meaning of repetition (istimrar tajaddud). 
Kata Kunci

Analisis struktur, makna stilistika, ayat khabariyyah
Abstrak

Al-Qur'an selalu menampilkan gaya bahasa dalam berbagai bentuk. Keberagaman struktur dan gaya bahasa al-Qur'an menunjukkan bahwa ada makna tertentu yang ditampilkan di balik teks ayat tersebut. Artikel ini bertujuan untuk mengungkap bentuk-bentuk struktur dan makna kebahasaan yang terkandung dalam ayat-ayat khabariyyah dalam al-Qur'an sehingga dapat memberikan alternatif pemahaman al-Qur'an yang tidak berpihak pada salah satu golongan. Serta dapat memberikan pemahaman makna yang jelas, terbuka apa adanya sesuai dengan bentuk struktur kalimat yang khas berupa tuturan dan makna yang terkandung di dalamnya. Metode yang digunakan adalah Teori Linguistik dengan mengumpulkan konfigurasi kalam khabariyyah kemudian menganalisis struktur dan maknanya melalui pendekatan analisis sintaksis dan semantik dalam penafsiran al-Qur'an. Artikel ini menyimpulkan bahwa konfigurasi struktur stilistika ayat-ayat dengan corak khabariyyah dalam al-Qur'an dinyatakan dalam dua konstruksi, yaitu pada konstruksi jumlah ismiyyah dan jumlah fi'liyyah dengan berbagai macam gaya bahasanya (uslub). ada : dalam gaya uslub al-Qashru, al-Taqdim wa al-Takhir, dan al-Qasam. Dari segi makna menunjukkan bahwa Jumlah ismiyyah memberikan makna yang tetap (Itsbat), abadi (Dawam) dan terus menerus (istimrar), sedangkan jumlah fi'liyyah memberikan makna terjadinya (huduts) yang berarti terjadinya suatu peristiwa di suatu tempat. waktu tertentu serta arti pengulangan (istimrar tajaddud).

\section{Introduction}

The discourse on the language of the Qur'an and its interpretation is a never-ending study. Theologically, the Qur'an is believed to be the language of God and uses Arabic (Surah Thaha [20]:113). The Qur'an always displays a different meaning from the previous interpretation. In other words, the Qur'an always provides innovative and valid things in every style of interpretation and reveals the meaning behind the language text of its verses. In other words, the Qur'an becomes shalih li kulli era wa eating (relevant to space and time). ${ }^{1}$ Submission of intent and information in the Qur'an is carried out using various language

\footnotetext{
${ }^{1}$ Arif Chasbullah and Wahyudi, "Deradikalisasi Terhadap Penafsiran Ayat-Ayat Qital," FIKRI: Jurnal Kajian Agama, Sosial dan Budaya 2, no. 2 (2017): 408.
}

styles, as Baalbaki calls it the language style or uslub ${ }^{2}$ or also known as stylistics.

Stylistics is one of the new terms in linguistic studies that is used in interpreting the Qur'an. According to Panuti Sudjiman as quoted by Damhuri, it is stated that the problems in the study of stylistics include an explanation of the preference for the use of words or the structure of language (stylistic features) that distinguish a work from other works. These characteristics can be phonological (sound patterns of language), syntactic (type of sentence structure or nahw/ qawaid) and lexical (diction, frequency of use of certain word classes or sharaf) and semantic

\footnotetext{
${ }^{2}$ Ramzi Munir Ba'albaki, Dictionary Of Lingusitik Term. English-Arabic, 1st ed. (Beirut: Dār al-Ilmi Lilmalaȳ̄n, 1990), 478
} 
(meaning of a word or sentence expression). This kind of study can help uncover the pattern of repetition which is an important characteristic of the cause of cohesion in a work. ${ }^{3}$ Understanding the structure and meaning contained in the verses of the Qur'an through this stylistic approach can at least provide an alternative understanding of the Qur'an that does not favor one group. This will also provide a clear and open understanding of the meaning as it is in accordance with the form of the sentence structure expressed in a distinctive language style in the form of aesthetic speech and the meaning contained in the Qur'an.

The aesthetic form of speech and meaning can be seen from the various forms of choice of lafaz and also the composition of the pronunciation of the verses of the Qur'an. In terms of the choice of lafadz, the Qur'an often uses lafadz which have the same (similar) meaning in Indonesian, for example Zauj (زوج) and imra'ah (إمر أة) which translates into the word wife. What is interesting is that if each lafadz has the same meaning, surely one lafadz with another can replace each other. For example, in the Qur'an, Eve is referred to as the zauj of the prophet Adam (Surah al-Baqarah [2]: 35; QS. al-A'raf [7]: 19; QS. Thaha [20]: 117). The wife of al-Azis (Surah Yusuf [12]: 30, and 51), Nuh, Lut and Pharaoh are described as imra'ah (Surat at-Tahrim [66]:10 and 11). In reality, however, this kind of substitution in the Qur'an never occurs. This indicates that each of these lafadz has a specific, distinctive meaning and the equivalent has not been found in the Indonesian language. If examined more deeply, the word zauj is shown in the context of the life of a husband and wife who are full of love and have children as in QS. ar-Rum [30]: 21, and QS. al-Furqan [25]: 74. Meanwhile, for family life where there is no or lack of affection due to treason, differences in aqidah or other reasons, it is described by the word imra'ah. For example,

${ }^{3}$ Damhuri, "Struktur Bahasa al-Qur'an : Membangun Elemen Stilistika Kebahasaan dalam al-Qur'an," Tahkim 10, no. 1 (2017): 192. imra'ah al-Azis in QS. Yusuf [12]: 30, and 51; imra'ah Noah, Lut and Pharaoh in QS. at-Tahrim [66]: 10 and 11.4

What is even more interesting for the author to examine further is the form of sentence expression in the khabariyyah (news/informative) verses which are arranged in the form of jumlah ismiyyah (nominal sentences) on the one hand and in the form of jumlah fi'liyyah (verbal sentences) on the other hand. For example, it is mentioned in QS. al-Fatihah [1]: 2, and QS. al-Jatsiyah [45]: 36 where the two verses are expressed in the form of ismiyyah sentence structure. However, the form of arrangement of the sentence structure of the two verses is different from one another. On the one hand, in this case, prioritizing the message (الحمد) over the message of khabar (ل) as stated in QS. al-Fatihah [1]: 2 and prioritizing the messageof khabar ( لـ) over the message of mubtada' nya (الحمد) as stated in the QS. al-Jatsiyah [45]: 36. If the arrangement of these sentences has the same meaning, of course it will be expressed in the same arrangement and editorial form. However, the expression of the two sentences is different from one another. This has implications for the different meanings contained in each of these verses. In the number of fi'liyyah as mentioned also in the Qur'an QS. al-Fatihah [1]: 5 and QS. al-Baqarah [2]: 7, the two verses are expressed in the form of a fi'liyyah sentence structure but with a different form of sentence structure. In QS. al-Fatihah [1]: 5, the sentence structure prioritizes maf'ul (object) (إياك) over Fi'il (predicate) (نعبد), while the sentence structure in QS. al-Baqarah [2]: 7 prioritizes fi'il (predicate) (ختم) which is then followed by fa'il (subject) (اله). If the sentence structure has the same meaning, of course it is expressed in the same arrangement and editorial form and in fact this is not the case. This has implications for the different meanings contained in each of these verses. Herein lies the

\footnotetext{
${ }^{4}$ Agus Tricahyo, "Stilistika al-Qur'an Memahami Fenomena Kebahasaan al-Qur'an dalam Penciptaan Manusia," Dialogia: Jurnal Studi Islam dan Sosial 12, no. 1 (2014): 54.
} 
aesthetic nuance regarding the placement of the grammatical semantics of the Qur'an. To achieve the purpose of the verse of the Qur' an above, it is necessary to understand and explain the meaning contained in the sentence structure although to achieve a correct and good understanding is not easy. Thus, we need a tool to achieve this goal through the science of interpretation. This paper will describe one form of structural rules for the jumlah ismiyyah and fi'liyyah from the language of the Qur'an by looking at the rules of uslub stylistics in the khabariyyah verses in the Qur'an.

This paper seeks to reveal the forms of linguistic structure and meaning contained in the khabariyyah verses in the Qur'an by using a Theoretical Linguistics approach ${ }^{5}$ عـم اللغــــ as the method of analysis. To facilitate the research process, the form of The Theoretical Linguistics approach used in this paper is syntactic and semantic analysis. This approach will reveal how the forms of linguistic structure and meaning or lughawiy patterns in the interpretation of the Qur'an from the khabariyyah verses in the Qur'an.

This paper is expected to provide an understanding of the various forms of structure and the meanings contained in the two forms of jumlah, both ismiyyah and fi'liyyah. In addition, it is hoped that this paper can be a reference in developing the theory of understanding the verses of the Qur'an in terms of syntactic and semantic aspects as well as developments in other linguistic research that takes the same object, namely the Qur'an. Thus, researchers can prove and show the existence of a very spectacular value charge in the language of the Qur'an known as i'jaz al-Qur'an.

\section{Stylistic Terminology}

The word stylistic comes from the root word stil (style) which means style. Quoting Gorys

\footnotetext{
${ }^{5}$ Theoretical linguistics is linguistics that prioritizes language research from an internal perspective, observing language from activities found in language involving various aspects, namely: Phonology, Morphology, Syntax and Semantics. See, Ade Nandang and Abdul Kosim, Pengantar Linguistik Arab, Bandung (Bandung: PT. Remaja Rosda Karya, 2018).
}

Keraf's opinion, Syihabudin Qulyubi in his book Stylistics of the Qur'an states that the word style is derived from the Latin word stilus, which is a kind of tool for writing on wax plates. Expertise in using this tool will affect whether or not the writing on the wax plate is clear. The time of emphasis when writing will be emphasized on beautiful writing skills, so that style will turn into the ability and expertise to write or use words beautifully. ${ }^{6}$ In terms of terminology, stylistics is the science of distinctive style or ways, how everything is expressed in a certain way so that the intended goal can be achieved optimally. Stylistics is also meaningful as a way of using language from someone in a context and for a particular purpose. ${ }^{7}$ Stylistics is also interpreted as a linguistic science that studies language styles. In linguistics, there is one study whose object is style, namely stylistics where the focus is on the study of language style. ${ }^{8}$ Stylistics is defined as a science that investigates the language used in literary works; interdisciplinary science between linguistics and literature. In Arabic literature, stylistics is known as 'ilm al-uslūb. ${ }^{9}$ The word uslub has the meaning of al-tariq wa al-wajh wa al-madzhab (method, tecnique and sect). ${ }^{10} \mathrm{In}$ a general sense, uslub is a way of writing or a way of choosing and arranging words to reveal a certain meaning so that it has a clear purpose and influence.

The opinion of 'Abd al-Qahar al-Jurjani, quoted by Ahmad Muzakki states that the meaning of uslub and siyaghah is the same. Both are defined as a way of delivery or a way of expression taken by a writer to describe something that is in himself, or to convey to

${ }^{6}$ Syihabudin Qulyubi, Stilistika al-Qur'an Pengantar Orientasi Studi al-Qur'an, Yogyakarta (Yogyakarta: Titian Illahi Press, 1997), 27-28.

${ }^{7}$ Lecce Geoffrey, Style in Fiction (London: Longman, 1984).

${ }^{8}$ Akhmad Muzakki, Stilistika al-Qur'an, Gaya Bahasa alQur'an dalam Konteks Komunikasi (Malang: UIN-Malang Press, 2009), 9.

${ }^{9}$ Ibid., 28.

${ }^{10} \mathrm{Ibnu}$ Manzur, Lisan al-Arab, second edition (Beirut: Dar al-Nasyr, n.d.), 178. 
others using the oldest language expressions, or a way of arranging words to reveal meaning so that it becomes clear and affects the soul of the reader. In other words, uslub is the way a writer or poet chooses some words and arranges them in a series of sentences, or how to create thoughts and expressions by using language styles that are according to the situation. ${ }^{11}$

Arab writers divide $u s l u b$ into three parts. The first is uslub khitabi where this uslub emphasizes eloquent expressions (ibarah jazlah), perfect sentences, influential innotations, which are then embellished with emphasis (intonation) and variations in conveying to others. The second is uslub ilmi which emphasizes strong logic, the beauty of language that satisfies the listener, the arrangement of arguments, and is reliable in rejecting doubts. The third is uslub adabi where this uslub uses gentle expressions, beautiful images and smooth delivery because it aims to satisfy emotions and arouse feelings. The definition of uslub adabi is different from the notion of uslub scientific. Uslub adabi is the language of emotion or feeling (lughah al-'atifah), while uslub 'ilmi is the language of ratio (lugah al-'aql). ${ }^{12}$

The division of uslub above is essentially inseparable from two main elements, namely elements of language and meaning (ideas, thoughts and ideas). Meanwhile, uslub has three characters consisting of al-juddah (beautiful), al-ijaz (concise), al-tala'um (appropriate) ${ }^{13}$. The indication of al-juddah is the use of beautiful words and expressions, while al-ijaz is showing the qualities that characterize a good uslub, and al-tala'um is the compatibility between sentences in terms of musicality, composition and beauty. To achieve this category, al-ziyat emphasized that uslub only occurs when: a) There is creativity in ideas or ideas (al-ma'na al-mubtakīr), and b)

\footnotetext{
${ }^{11}$ Ahmad Muzakki, 14.

${ }^{12}$ Ibid.

${ }^{13}$ Rosihan Anwar, Ilmu Tafsir (Bandung: Pustaka Setia, 2005), 20-26.
}

There is a beautiful style of language as a medium of ideas and ideas (al-sura al-jayyīdah). ${ }^{14}$

The notion of stylistics in the Qur'an is no different from the understanding of stylistics in general. Statistics in the Qur'an are both definitions of the science that investigates the language used in the Qur'an. Citing the opinion of M.H. Ibrams, Khafaji said that the characteristics of stylistic studies include issues related to sawthiyah (phonology), jumliyah (various sentence structures), mu'jamiyah (lexicology), and balaghiyah (such as the use of language metaphors, hypalase, mythonyms and many more). ${ }^{15}$ The same thing about the characteristics of the uslub of the Qur'an was expressed by Wahbah al-Zuhaili including: first, the sentence structure is beautiful, rhythmic, and has amazing rhymes so that it can distinguish it from other expressions, both in the form of poetry, prose and speech. Second, the choice of lafadz, structure, and beautiful expressions. Third, the softness of the sound in composing the surah. Fourth, the suitability of pronunciation and meaning. ${ }^{16}$ Thus, it can be said that the aspects of language studied in the stylistics of the Qur'an are also the same, including aspects of phonology, pronunciation preferences, sentence preferences, and deviations. ${ }^{17}$ The focus of the author's attention in this discussion is on the form of sentence preference used in the construction of the sentence structure (jumliyah) of the Qur'anic verse and the implications of the meaning it causes.

Actually, discussing the stylistics of the Qur'an cannot be separated from the concept of i'jaz al-Qur'an itself considering that stylistics of the Qur'an is a science that studies the language used by the Qur'an. An example in this case is the selection of letters and the combination of

\footnotetext{
${ }^{14}$ Ahmad Muzakki, 15.

${ }^{15}$ Muhammad 'Abd Munim, et.al., al-Uslubiyah wa al-Bayan al- 'Arabi (Beirut: al-Dar al-Misriyah al-Lubnaniyah, 1992), 14. ${ }^{16}$ Wahbah al-Zuhaili, al-Tafsir al-Munir di al-'Aqidah wa alShari'ah wa al-Manhaj, Juz I (Damaskus: Dar al-Fikr, 2005), 35. ${ }^{17}$ Ahmad Muzakki, 64-71.
} 
consonants and vowels that match making it easier to pronounce. Likewise, the choice of lafa for example the lafaz of mar'a (مر عى) in the Surah of al-Naziat [79]: 31 which contains the meaning of covering all types of consumptive plants, such as root vegetables, grasses, beans and so on, but it is enough to use one word, namely mar' $a$, which means food for humans and livestock. ${ }^{18}$

\section{Kalâm Khabar}

Kalâm khabar consists of two syllables kalâm and khabar. According to Zamakhsari, kalâm means:

\begin{abstract}
Al-kalâm huwa al-murakkab min kalimataini usnidad ihdaahumaa 'ala al-ukhra, wa haza laa ya'ti illa fi ismaini au fi fi'lin wa ismin wa sumiya al-Jumlah. ${ }^{19}$ (Kalam is the arrangement of two words that are based on one another, this can apply to two isims or to fi' $i l$ and isim and is called the number).
\end{abstract}

The above understanding explains that the term kalam referred to by Zamakhsari is the same as the number. He said that the number is a sentence structure consisting of musnad and musnad ilaih, both of them are isim or isim and fi'il. Meanwhile, Ibn Ya'isy gives the understanding that the number is a sentence structure consisting of mubtada' and kalâm or consisting of fi'il, fa'il and maf'ul bih. Thus, it can be understood that the words kalam and jumlah have substantially the same meaning. The difference lies only in terms of the use of terms, where Zamakhsari tends to use the term kalâm while others use the term quantity.

What is meant by khabar in this discussion is:

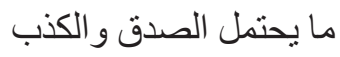

\section{"Something that contains elements of truth and elements of lies ${ }^{6} 20$}

Thus it can be said that kalâm khabar is:

\footnotetext{
${ }^{18}$ Ibid., 16.

${ }^{19}$ Lait As'ad abdul Hamid, al-Jumlah al-Washfiah fi al-Nahwi al-'Arabi (Kulliyatuh al-Adab al-Jami'ah al-Mustanshiriyah, 1984), 3-4.

${ }^{20}$ Bin 'Isa Bithahir, al-Balaghotul 'Arabiyah Muqaddimat wa alTathbiqat (Beirut: Dar al-Kitab al-Jadidah, 2008), 47.
}

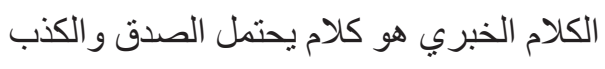

"Sentences that contain the meaning of right
and wrong."

The meaning of the truth here is the suitability of the sentence or statement with reality, while the lie is the lack of compatibility between the sentence or statement with reality. ${ }^{21}$ True or not a khabar can be known based on four opinions:

1. Jumhur al-Balaghiyyin (the majority of Balaghah experts) is of the opinion that the truth of a news story is if it is in accordance with reality and is said to be a lie if it happens otherwise, regardless of the existence of other beliefs than mutakallimin. That opinion is correct.

2. In contrast to Jumhur Balaghiyyin, alNadham $^{22}$ argues that the true news is in accordance with the belief of the mutakallim even though the belief is wrong. On the other hand, it is false news, even though the truth is true.

3. The opinion of al-Jahidz ${ }^{23}$ (followers of alNadham) states that the true news is that which is based on reality and mutakallim belief. While fake news is the opposite. Furthermore, he stated that if the news is the same as reality but different from belief or vice versa, then the news is characterized as news that is not true and is not a lie. ${ }^{24}$

4. The opinion of al-Raghib supports the opinion of al-Nadham. ${ }^{25}$

\footnotetext{
${ }^{21}$ See, al-Khatib al-Qazwaini (D. 739 H), Talkhis al-Miftah, Tahqiq Yasin al-Ayubi, first edition (Beirut: al-Maktabah al'Ashriyah, 2002), 47.

${ }^{22} \mathrm{He}$ is Ibrahim bin Sayyah al-Balkhi, one of the leaders of the Mu'tazilah (D. $231 \mathrm{H}$ ). See, Khairuddin al-Zarkaly, al- 'A'lam, vol. I (Beirut: Dar al-'Ilmy Lilmalayiin, n.d.), 43.

${ }^{23} \mathrm{He}$ was Abu Uthman Umar bin Bahr al-Jahiz, one of the students of al-Nadzam (D. 255 H), the Imam of Language and Literature in his time, wrote many books, one of which is the famous book al-Bayan wa al-Tabyiin. See, Khairuddin al-Zarkaly, vol 5, 74.

${ }^{24} \mathrm{Bin}$ 'Isa Bithahir, 50.

${ }^{25}$ Khamim dan H. Ahmad Subakir, Ilmu Balaghah Dilengkapi Dengan Contoh-Contoh Ayat, Hadis Nabi dan Syair (Kediri: IAIN Kediri Press, 2018), 16-17 .
} 
Basically, every kalâm khabar cannot be separated from isnad in which there is a musnad and musnad ilaha. Isnad generally contains the meaning of:

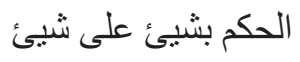

"assign something (musnad) over something else (musnad ilaih)”.

In another context, isnad is:

$$
\text { النسبة التي بين المسند و المسند إليه }
$$

"The nisbat between the musnad and the illaih musnad." 26

If the musnad consists of fi' $i l$ or equivalent, such as mashdar, ism fâ'il and ism maf' $u l$, it has several links (muta'alliqat) with other sentences that cannot stand alone, such as fa' 'il, maf'ull bih, etc. Therefore, each jumlah has two main pillars, namely:

1. Musnad Ilaih, which has a matter to be discussed ( صاحـب الأمـر المتحـدث عنـه ) or something that occupies the position of mubtada' in the ismiyyah number, and fa' $i$ in the fi'liyyah number.

2. Musnad, which is a matter that is given to musnad iiaih (الأمـر المعطـى إلـى المسـند إلبه) or something that occupies the position of khabar in the ismiyyah number, and fi'il in the fi'liyyah number.

Appart from these two pillars, it is called qayyid (قيدا) or muta'alliqat al-fi'il (متعلقات الفعل).27 The reference of musnad with musnad ilaih is called isnad (الإسـناد). For example in the Qur'an QS. al-Zumar [39]: 62 it is stated:

"Allah created all things and He maintains all things."

Lafaz (اله) is musnad ilaih, whie lafaz (خالق) is musnad. Apart from these two pillars, it is called

\footnotetext{
${ }^{26}$ Ibid., 13.

${ }^{27}$ Bin 'Isa Bithahir, 109.
}

qayyid, like the word كُلِّنَيْيك al-Ankabut [29]:44 that:

"Allah created the heavens and the earth with rights. Verily in that are the signs of Allah's power for the believers."

Lafaz (خلق) is musnad, while lafaz (اله) is musnad ilaih. Apart from these two pillars, there are qayyid as said by al-Samawaat wa al-Ardh

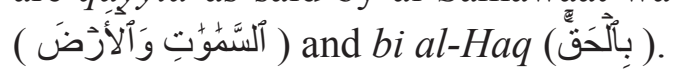

\section{Stylistics of Khabariyyah Verses in the Qur'an}

Based on the results of the study on the structural characteristics of the number (sentences) of the khabariyah verses in the Qur'an, in general they can be distinguished in two forms consisting of:

\section{Jumlah Ismiyyah}

Among the methods of interpretation related to language is the isim method. There are many sentences found in the Qur'an which are expressed in the form of jumlah ismiyyah (nominal sentences) with all forms of language style variations (uslub) which at the same time show the specificity of their meaning. Muhammad Cizrin $^{28}$ as quoted by Syafrijal stated that the jumlah ismiyyah (nominal sentences) generally indicates the meaning of tsubut (permanent) and istimrar (continuous).$^{29}$ However, of course there are other specific meanings that can be understood from the various forms of uslub, including:

a. Sometimes the jumlah ismiyyah is in the form of kalâm mutsbit (positive sentences) which begins with the element of mubtada' or musnad ilaih (subject) and is accompanied by an element of khabar or musnad (predicate) which aims to show the legal provisions of something (Itsbath) and eternal (dawam). Forms of $u s l u b$ which is like this can be seen

\footnotetext{
${ }^{28}$ Muhammad Cizrin, al-Qur'an dan Ulumul Qur'an (Jakarta: PT.Dana Bhakti Prima Yasa, 1998), 240.

${ }^{29}$ Syafrijal, “Tafsir Lughowi,” Jurnal Al-Ta'lim 1, no. 5 (2013): 425.
} 
for example in the Qur' an of QS. al-Fatihah:1

"Praise be to Allah, Lord of the worlds."

The sentence structure of the verse above indicates that the word الحمـ is mubtada' (musnad Ilaih) and the word a is khabar (musnad) in the form of syibhul sum, jar majrur (جرمجـرور ). In this case, the sentence structure is in the form of prioritizing mubtada' (musnad Ilaih) than khabar (musnad). Dealing with the form of the sentence structure, it shows the leaning of the word الحمــ (praise) to the word Whis gives meaning to the determination and continuity of the nature of praise for Allah SWT.

Further in QS. al-Zumar [39]: 23 asserted: "Allah has sent down the best words, that is the Qur'an which is similar (quality of its verses) over and over again, the skin of those who fear their Lord tremble, then their skin and hearts become calm at the remembrance of Allah. That is Allah's guidance, with that book He."

It can be seen at the sentence structure of the verse above, thus, it looks that the verse starts with the word as mubtada' or musnad ilaih (subject), while the word نز or musnad (predicate). And apart from the two called qayyid or complement. It has stated in verse 62:

"Allah created all things and Allah maintains all things."

Based on the sentence structure of the verse above, it can be seen that the word اله is mubtada'or musnad ilaih (subject). While the word خلقas khabar or musnad (predicate).

When it is viewed from the side of the meaning, it contained in the sentence structure of the two verses above, it shows the determination for Allah SWT as the creator of all things and who sent down the book of the Qur'an and no one other than Himself. And the decree is eternal and everlasting. Then in QS. al-Baqarah [2]: 255, asserts that:

"Allah, there is no God (who has the right to be worshiped) but he who lives eternally and continuously takes care of (His creatures); no sleep and no sleep. To Him belongs what is in the heavens and in the earth. no one can intercede with Allah without His permission? Allah knows what is before them and what is behind them, and they know nothing of Allah's knowledge except what He wills. Allah's seat covers the heavens and the earth. And Allah does not find it difficult to maintain them, and Allah is Most High, Most Great."

The sentence structure of the verse above is asserted in the form of the number of ismiyyah, where the word is mubtada' or musnad ilaih (subject) while the number of khabariyah is khabar or musnad (predicate) which prioritizes mubtada' than khabar. In this case, definitely, provides an understanding in terms of the meaning of the decree for Allah SWT as the God who lives and continuously takes care of his creatures. So the verse contains the meaning of dawam or istimrar. Likewise the use of the Ismiyyah contained in QS. al-Kahf [18]:18.

"And you think they are awake, but they are sleeping; And we turned them right and left, while their dog stretched out his arms in front of the cave door. And if you had seen them you would have turned away from them by fleeing and surely (your heart) would have been filled with fear towards them.

The sentence هـم رقـود in the verse above is expressed in the form of the number of ismiyyah (nominal sentence) where the word functions as mubtada' or musnad Ilaih while 
the word رقود is khabar mubtada' or musnad. If it is viewed from the structure of the wording in the verse, it shows the meaning that the young cave dwellers slept for a very long time and their bodies did not change. Then this is also expressed in QS. al-Hijr [15] : 45.

"Verily, those who are pious will be in Paradise (gardens) and (near) springs of (flowing) water."

Seeing from the structure of the wordin the verse using the same pattern, namely the word المتقبـن as the subject (musnad Ilaih) and the word order فيجناتو عيـون is the predicate (musnad). This has the meaning to show the promise of heaven or a very high reward for pious people which is permanent and does not change.

b. Sometimes the number of ismiyyah (nominal sentences) is in the form of kalam mutsbit (positive sentences) which begins by prioritizing the element of khabar (predicate) or musnad, and then followed by mubtada' (subject) or musnad ilaih the opposite of the previous form or also known as al-taqdim ma haqqahu al-ta 'khir. As in QS. al-Jatsiah [45]: 36.

"For Allah be all praise, Lord of the heavens and Lord of the earth, Lord of the world."

When it is viewed from the structure of the verse above, it can be seen that the verse begins with the word of فl namely as khabar or musnad (predicate). While the word الحمـ as mubtada 'mu'akkhar or musnad ilaih (subject). And apart from the two words it is called qayyid or complement. The form of the sentence structure that prioritizes khabar over mubtada' can be understood that the verse gives a special meaning, meaning that praise is only specifically for Allah, there is no possibility for others, in this case the dialectic of the speech shows determination and specificity for Allah in the form of dawam (forever) and istimrar (continously). The same understanding that can be understood from QS. ar-Rum [30]: 4 of the following:

"In a few more years, it is for Allah before and after (they won). and on that day (the victory of the Romans) those who believe will rejoice."

The redaction on structure of the verse above shows that the word is khabar or musnad (predicate), while the word الأمـر is mubtada' or musnad Ilaih (subject). The precedence of the word khabar (musnad) from mubtada' (musnad Ilaih) in the verse gives an understanding that this matter is a decree and a specialty for Allah SWT alone without interference from other parties.

c. Sometimes the number of ismiyyah (nominal sentences) is in the form of kalam manfi (negative sentences) by using the letters Nafi' and Istitsna'. As in QS. al-Maidah [5]: 75, QS. al-Shad [38]: 65, and QS. al-An'am [6]: 90. "Al is still the son of Maryam, but he is only an Apostle. Indeed, several messengers have passed before, and his mother was a very righteous person, both of whom used to eat food. watch how We explain to them (the people of the Book) the signs of (Our) power, Then watch how they turn away (from paying attention to our verses)."

The sentence structure of the verse above starts with the letter of nafi $\llcorner$ accompanied by the letters istitsna ' إ then it is followed by the word المسيـيح ابن مريـم which is the musnad ilaih as well as al-mustatsna minhu, and then the word رسولis the musnad as well as the almustatsna of إل Thus, it can provide a strong understanding and belief about the apostleship 
of Prophet Isa as. And it has become a decree from Allah SWT which is dawam (eternal) and istimrar (continuous). Likewise, QS.Shad [38]: 65.

"Say (O Muhammad): "Indeed I am only a warner, and there is absolutely no god but Allah is the One and the All-Knowing."

The sentence structure of the verse also uses the letter of nafi " " "accompanied by the

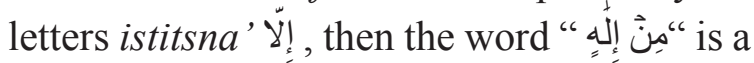
musnad ilaih as well as al-mustatsna minhu,

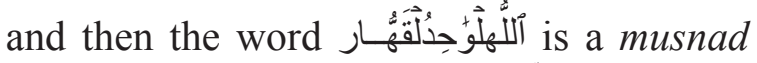
as well as al-mustatsna from إنّ . Thus, the stylistic arrangement of the verse gives the meaning of specialization in the form of uslub al-Qashru (limitation), namely the word of

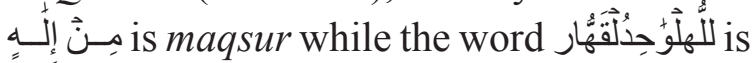
maqsur 'alaih, the editorial of the above lafaz indicates that there is a limit on the adjective إِل to the maushuf d means that the meaning of the verse above shows that the determination of Uluhiyah (God) is nothing but Allah SWT alone, nothing more than that and is dawam (eternal) and istimrar (continuous).

d. Sometimes the number of ismiyyah (nominal sentences) is preceded by one of the Tauhid letters, including:

1. By using the taukid letter إنــ, as in QS. al-Nahl [16]: 51, al-Hujurat [49] : 10, Fatir [35]: 28.

"Allah says: "Do not worship two gods; Verily, He is the One God, so you should only fear Me."

The redaction of the verse above shows that the word "huwa" is mubtada' and the word "Ilahun Wahid" is his khabar. Thus it can be understood that Allah SWT has determined that He is one God. Likewise with QS. Hujurat [49]: 10.

"The believers are indeed brothers. Therefore make peace (improve relations) between your two brothers and fear Allah, so that you may receive mercy."

The redaction of the verse above shows that the word "al-mukminun" is mubtada" and the word "ikhwatun" is his khabar. Thus it can be known that Allah SWT has determined that the believers are brothers.

"And so (also) among humans, reptiles and livestock there are various colors (and types). Indeed, those who fear Allah among His servants are only scholars. Verily Allah is Mighty, Most Forgiving." 30

In terms of the sentence structure, it can be seen that the arrangement of the verses above begins with the letter " "إنََّْ" which is accompanied directly by the word of يَخَشَى أَلَّه as khabar muqaddam/ musnad (prediket)/maqsur, while the word as mubtada' mu'akkhar/ musnad ilaih (subject)/ maqsur 'alaih. The form of the sentence structure in this verse uses the al-Qashru language style by using

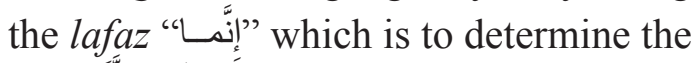
word يَخَشَى أَلَّهَ as its maqsur to its maqsur 'alaih العلمـاء. Thus, the stylistic structure of this kind contains the meaning of itsbat خشـية اللهابة (determination) of the nature of (fear of Allah) that is nothing but العلىـاء alone, nothing more.

2. Dengan huruf taukid أل (li Tanbih), as the word of God in QS. al-Baqarah [2]: 13.

"When it is said to them: "Believe as others have believed". They replied: "Shall we believe as the ignorant people have believed?" Remember, verily they are the fools; but they don't know."

\footnotetext{
${ }^{30}$ QS. al-Fatir: 28.
} 
3. With Dhamir Fashal which functions as a reinforcement (li al-taukid), as the word of God in QS.al-Baqarah [2]: 5.

"They are the ones who continue to receive guidance from their Lord, and they are the lucky ones."

Dhamir Fashal $ه$ at the end of the verse above which separates the mubtada' أولئك and khabar المفلحــون has function as sentence reinforcement.

\section{Number of Fi'liyyah}

Manna'Khalil al-Qattan ${ }^{31}$ explains that the number of fi'liyah or verbal sentences shows the meaning of tajaddud (the emergence of something) and hudus (temporal). As for what is meant by tajaddud in fi'il madhi (past verb) is that the action arises and sinks, sometimes it exists and sometimes it doesn't exist. While in fi'il mudhari' (present or future verb) the action occurs repeatedly.

An explanation that is meaningful to what al-Qattan conveyed, was revealed by al-Suyuti ${ }^{32}$ that the khitab with fi'il shows the meaning of tajaddud and huduts. According to him what is meant by tajaddud in fi' 'il madhi is the result (al-hushul) and in fi 'il mudari' it is repeated. Likewise, Al-Hasyimi emphasized the meaning of "istimrar at-tajaddudi" (the period continues over and over again). In the presence of qarinah (relationship) when the fi' $i l$ is in the form of $f i$ ' $i l$ mudhari, ${ }^{33}$

The form of the rule for the number of fi'liyah can be seen in the verse where the editorial uses $\mathrm{Fi}$ 'il as follows:

Sometimes this number of fi'liiyyah (verbal

\footnotetext{
${ }^{31}$ Manna" Khalil al-Qattan, Studi Ilmu-Ilmu Qur'an, translatied by Mudzakir AS, 12th edition (Bogor, Pustaka Litera Antar Nusa, 2009), 291-292.

${ }^{32}$ Al-Suyuti, Al-Itqan Fi 'Ulum al-Qur'an ( Beirut: Dar al-Fikr, n.d.), 199

${ }^{33}$ Sayyid Ahmad al-Hasyimi, Jawahir al-Balaghoh fi al-Ma'ani wa al-Bayan wa al-Badi' (Beirut, Maktabah al-'Ashriyyah, n.d.), 66 .
}

sentences) immediately begins with fi'il or musnad (predicate) and is accompanied by fa'il or musnad ilaih (subject), as in QS. al-Ankabut [29]: 44.

"Allah created the heavens and the earth with rights. Verily in that are the signs of Allah's power for the believers."

When it is viewed from the structure of the verse above, it can be seen that the verse begins

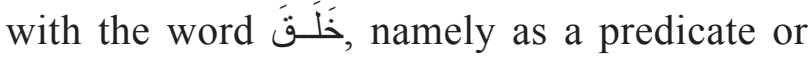
fi'il or musnad, or mukhbir bih. While the lafaz (word) لٌّ is as a subject or fa'il or musnad ilaih, or al-mukhbir 'anhu. And apart from the two words (words) are called qayyid or complement (complement).

When it is viewed from the side of the meaning to be conveyed to the mukhattab, it can be understood that the events of the creation of the heavens and the earth by Allah SWT have occurred and took place in the past.

Sometimes the redaction of composition on the number of fi'liyah is by prioritizing maf'ul (object) than fi'il and fa'il, as stated in QS. alFatihah [1]:5, namely:

"Only You we worship ${ }^{34}$, and only to you we ask for help." $" 35$

The word (نَعَبُد) and (نَتَنَعِعِنُ) in the verse above it is fi' $i l$ and fa' $i l$ while maf'ul is the word 5) whose pronunciation structure precedes $f i$ 'il and $f a$ ' $i l$. Then if you look at the second form of fi'il expressed in the form of fi'il mudhari', this can provide an understanding that the work of worshiping Allah SWT and asking Him for help must be done repeatedly (tajaddud) and continuously (istimrar) without exception, while prioritizing the arrangement of maf'ul over its

\footnotetext{
${ }^{34} \mathrm{Na}$ 'budu taken from the word 'ibadah: obedience and submission caused by feelings of the greatness of Allah, as the God who is worshiped, because they believe that Allah has absolute power over them.

${ }^{35}$ Nasta'iin (ask for help), taken from the word isti'aanah: expecting help to be able to complete a job that cannot be done with one's own power.
} 
fi'il and fa'il as stated by Ibn Kathir ${ }^{36}$ giving the meaning of lil ihtimam bih and lil ikhtishar means showing attention and boundaries whose understanding provides an understanding of the emphasis and virtue of Allah SWT as the One who deserves to be worshiped and a place to ask for help and not to others. Sometimes the number of fi'liyyah starts with various letters, including:

The letter of Qasam (sumpah) which functions as sentence of reinforcement, as stated in QS. alAnbiya' [21]: 57.

"By Allah, I will deceive your idols after you leave them."

The verse above begins with sighat (form) qasam, i.e. letter qasam of $ت$, then followed by muqsam bih اله , then followed by muqsam 'alaih

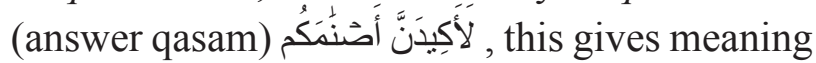
as a well-known word amplifier to strengthen the truth something in the soul, as affirmed by al-Qattan ${ }^{37}$ that the Qur'an was revealed to all humans, and people have different attitudes towards it. Among them there are those who doubt, there are those who deny and some are very hostile. Therefore, the form of qasam is used in Kalamullah, in order to eliminate doubts, eliminate misunderstandings, establish evidence, strengthen news and establish the law in the most perfect way.

The letter of قـد which has function as a sentence reinforcement, as the word of God in QS. al-'A'la [87]: 14.

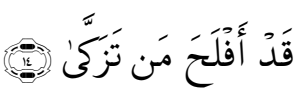

"Indeed, successful is he who cleanses himself (by faith)."

The letter of $ـ$, as Allah says in QS. alBaqarah [2]: 120.

"The Jews and the Christians will not be

\footnotetext{
${ }^{36}$ Abil Fida' Ismail ibnu Umar ibnu Katsir al-Quraisyi alDimasyqy (D. 701-774 H), Tafsir al-Qur'an al-'Azhim, 1st edition (Beirut, Dar Ibnu Hazm, 2000), 70.

${ }^{37}$ Manna' al-Qattan, 415.
}

pleased with you until you follow their religion. Say: "Verily Allah's guidance is the (true) guidance". And verily if you follow their will after knowledge comes to you, then Allah will no longer be your protector and helper."

The letter of min az-zaidah ( من الزائدة ) which has function as a sentence reinforcement, as Allah says in QS. al-Maidah [5]: 19.

"...there has not come to us neither a bearer of glad tidings nor a warner". Verily, there has come to you a bearer of glad tidings and a warner. Allah has power over all things."

The letter of nafi and Istitsna', as Allah says in QS. al-Dzariyat [51]: 56.

"I did not create the jin and mankind except to worship Me."

Dealing with the examples of khabariyyah verses that are preceded by letters as stated above, it shows the existence of a taukid (reinforcing) function and at the same time strengthens the content of the news contained in the editorial of the verse. Thus, the existence of the letter shows the strengthening of the meaning contained in the verse, namely strengthening the belief in the existence of the law contained in the expression of the sentence.

\section{Conclusion}

Regarding to the description above, it can be concluded that the stylistics of the style of the Qur'anic language, especially the khabariyyah verses have a variety of meanings based on the characteristics of the sentence structure used. The form of the stylistic structure of the khabariyyah verses in the Qur'an is asserted in two forms, namely in the form of ismiyyah numbers and fi'liyyah numbers with various forms of $u s l u b$ variations, including: in the form of uslub alQashru (shortening), al-taqdim ma haqqahu al-takhir (prioritizing something that should be ended), and al-qasam (oath). In terms of 
meaning, it finds out that the number of ismiyyah gives the meaning of Itsbath (decision) which is dawam (continuous or eternal), while the number of fi'liyyah gives the meaning of huduts and Istimrar tajaddud, namely information about the occurrence of an event at a certain time (time) and tikrar (repeatedly).

\section{References}

'Abd Munim, Muhammad. Al-Uslubiyah Wa al-Bayan al-'Arabi. Beirut: al-Dar alMisriyah al-Lubnaniyah, 1992.

Al-Qattan, Manna'. Studi Ilmu-Ilmu Qur'an. 12th ed. Bogor: Pustaka Litera Antar Nusa, 2009. Al-Qazwaini, al-Khatib. Talkhis al-Miftah Tahqiq Yasin al-Ayubi. 1st ed. Beirut: AlMaktabah al-'Ashriyah, 2002.

Al-Suyuti. Al-Itqan Fi 'Ulum al-Qur'An. Beirut: Dar al-Fikr, n.d.

Al-Zarkaly, Khairuddin. Al- 'A'Lam. vol. 1. Beirut: Dar al-'Ilmy Lilmalayiin, n.d.

Anwar, Rosihan. Ilmu Tafsir. Bandung: Pustaka Setia, 2005.

Ba'albaki, Ramzi Munir. Dictionary Of Lingusitik Term. English-Arabic. 1st ed. Beirut: Dār al-Ilmi Lilmalaȳ̄n, 1990.

Bithahir, Bin 'Isa. Al-Balaghotul 'Arabiyah Muqaddimat Wa al-Tathbiqat. Beirut: Dar al-Kitab al-Jadidah, 2008.

Chasbullah, Arif, and Wahyudi. "Deradikalisasi Terhadap Penafsiran Ayat-Ayat Qital.” Fikri: Jurnal Kajian Agama, Sosial dan Budaya 2, no. 2 (2017): 408.

Cizrin, Muhammad. Al-Qur'an dan Ulumul Qur'an. Jakarta: PT. Dana Bhakti Prima Yasa, 1988.

Damhuri. "Struktur Bahasaal-Qur'an: Membangun Elemen Stilistika Kebahasaan Dalam alQur'an.” Tahkim 10, no. 1 (2017): 192.

Geoffrey, Lecce. Style in Fiction. London: Longman, 1984.

al-Hasyimi, Ahmad. Jawahir al-Balaghoh Fi al-
Ma'ani Wa al-Bayan Wa al-Badi'. Beirut: Al-Maktabah al-'Ashriyah, n.d.

Katsir, Ibnu. Tafsir al-Qur'an al- 'Azhim. 1st ed.

Beirut: Dar Ibnu Hazm, 2000.

Kemenag. Qur'an. Jakarta: Lajnah Pentashihan Mushaf al-Qur'an Badan Litbang dan Diklat Kemenag RI, 2019.

Manzur, Ibnu. Lisan al-Arab. 2nd ed. Beirut: Dar al-Nasyr Lisan al-Arab, n.d.

Ma'zah, Rabih. Al-Jumlah Fi al-Qur'an al-Karim Suwaruha Wa Taujihuha al-Bayaniy. Dar Muassasah Ruslan littibaa'ah wa al-Nasyr wa al-Tauzi', 2008.

Muzakki, Akhmad. Stilistika al-Qur'an, Gaya Bahasa al-Qur'an dalam Konteks Komunikasi. Malang: UIN-Malang Press, 2009.

Nandang, Ade, and Abdul Kosim. Pengantar Linguistik Arab. Bandung: PT. Remaja Rosdakarya, 2018.

Qulyubi, Syihabudin. Stilistika al-Qur'an Pengantar Orientasi Studi al-Qur'an. Yogyakarta: Titian Ilahi Press, 1997.

Ratna, Nyoman Kutha. Stilistika Kajian Puitika Bahasa Sastra dan Budaya. Yogyakarta: Pustaka Pelajar, 2013.

Sopian, Asep. "Stilistika Dialog Qur'an dalam Kisah Nabi Nuh as." Bahasa dan Seni: Jurnal Bahasa, Sastra, Seni dan Pengajarannya 45, no. 2(2017): 181-196. Subakir and Khamim, Ahmad. Ilmu Balaghah Dilengkapi dengan Contoh-contoh Ayat, Hadis Nabi dan Syair. Kediri: IAIN Kediri Press, 2018.

Syafrijal. "Tafsir Lughowi." Al-Ta'lim Journal 20, no. 2 (2013): 425.

Tricahyo, Agus. 'Stilistika al-Qur'an Memahami Fenomena Kebahasaan al-Qur'an aalam Penciptaan Manusia.” Dialogia: Jurnal Studi Islam dan Sosial 12, no. 1 (2014): 54. Zuhaili, Wahbah. Al-Tafsir al-Munir Fi al'Aqidah Wa al-Shari'ah Wa al-Manhaj. Juz I. Damaskus: Dar al-Fikr, 2005. 